\title{
TLR9 Signaling Failure Renders Peyer's Patch Regulatory B Cells Unresponsive to Stimulation with CpG Oligodeoxynucleotides
}

\author{
Jayaum S. Booth ${ }^{a}$ Ryan Arsenault ${ }^{a, b}$ Scott Napper ${ }^{a, b} \quad$ Philip J. Griebel $^{a}$ \\ Andrew A. Potter ${ }^{\mathrm{a}} \quad$ Lorne A. Babiuk $^{\mathrm{d}}$ George K. Mutwiri ${ }^{\mathrm{a}, \mathrm{c}}$ \\ ${ }^{a}$ Vaccine and Infectious Disease Organization/International Vaccine Center, ${ }^{b}$ Department of Biochemistry \\ and 'School of Public Health, University of Saskatchewan, Saskatoon, Sask., and ' University of Alberta, \\ Edmonton, Alta., Canada
}

\section{Key Words}

Regulatory B cells $\cdot$ Pattern recognition $\cdot$ Toll-like

receptors $\cdot \mathrm{CpG}$ oligodeoxynucleotides P Protein kinases ·

Kinome analysis $\cdot$ Peyer's patches

\begin{abstract}
Intestinal Peyer's patch (PP) regulatory CD21+ B cells ( $\left.B_{\text {regs }}\right)$ suppress TLR9-induced innate immune responses. However, it is not known whether TLR9 activation is regulated in PP $B_{\text {regs. }}$. Here, we investigated the responses of $P P B_{\text {regs }}$ to stimulation with the TLR9 agonist CpG oligodeoxynucleotides (ODN). We observed that PP CD21+ $B_{\text {regs }}$ express high levels of TLR9 mRNA, but fail to proliferate when stimulated with CpG ODN. Furthermore, unlike CD21+ B cells from blood, PP CD21+ $B_{\text {regs }}$ do not secrete IgM or IL-12 following CpG ODN stimulation. We hypothesized that the unresponsiveness of $P P B_{\text {regs }}$ to $C p G$ stimulation was due to an inability of the TLR9 agonist to activate the TLR9 signaling pathway in these cells. This was confirmed by kinome analysis which demonstrated dynamic patterns of phosphorylation of key TLR adaptor proteins such as IRAK1, TAK1, IKK and NF-KB-p65 in CpG-stimulated blood CD21+ B cells, consistent with activation of the TLR9 pathway. In contrast, stimulation of PPCD21+ $B_{\text {regs }}$ with CpG ODN resulted in phosphorylation patterns of these adaptor proteins suggestive of inactivation of the TLR9 pathway. The absence of apparent TLR9 signaling events im-
\end{abstract}

mediately following stimulation indicated that signaling is blocked close to the receptor. Our observations suggest a novel mechanism by which the host regulates TLR responses in TLR-expressing cells with regulatory functions.

Copyright $\odot 2010$ S. Karger AG, Basel

\section{Introduction}

Toll-like receptors (TLR) are the most studied family of pattern recognition receptors. They have been found to be important in the detection of microbial threats and play an essential role in the induction of immune responses [1]. TLR are expressed by cells of innate and adaptive lineages and recognize an array of pathogen-associated molecular patterns including single-stranded RNA [2] and bacterial DNA containing CpG motifs [3]. Activation of TLR9 by CpG DNA leads to recruitment of downstream adaptor molecules including MyD88, IRAK1, TAK1, IKK- $\alpha$, IKK- $\gamma$, p-38, JNK and Fos, which subsequently trigger NF- $\mathrm{B}$ and/or AP-1. This leads to upregulation of innate immune response genes resulting in production of proinflammatory cytokines, type I interferons and cell proliferation. In humans [4] and in ruminants [5], the main cell populations that express TLR9 and are directly activated by $\mathrm{CpG}$ oligodeoxynucleotide $(\mathrm{ODN})$ are $\mathrm{B}$ cells and plasmacytoid dendritic cells.

\section{KARGER}

Fax +4161306 1234

E-Mail karger@karger.ch

www.karger.com
(C) 2010 S. Karger AG, Basel

$1662-811 X / 10 / 0025-0483 \$ 26.00 / 0$

Accessible online at:

www.karger.com/jin
Dr. George K. Mutwiri

School of Public Health and Vaccine and Infectious Disease Organization/

International Vaccine Center, University of Saskatchewan

120 Veterinary Road, Saskatoon, SK S7N 5E3 (Canada)

Tel. +1 306966 7472, Fax +1 306966 7478, E-Mail george.mutwiri@ usask.ca 
Interestingly, several studies have found that B cells, which are adaptive immune cells, constitutively express TLR, mainly TLR1 and TLR6-10 [6,7], and can be activated by TLR agonists in the absence of antigen. $\mathrm{B}$ cell activation by the TLR9 agonist CpG ODN was first reported by Krieg et al. [8], who found that in vitro and in vivo stimulation of murine $B$ cells with $\mathrm{CpG}$ ODN induced cell proliferation and secretion of immunoglobulins. Subsequently, CpG ODN has been shown to directly stimulate B cells to secrete immunoglobulins in mice [9] and also to secrete the cytokines IL-6, IL-12 and IL-10 [10]. In humans, significant induction of immunoglobulin secretion by $\mathrm{CpG}$-activated B cells requires additional signals such as B cell receptor cross-linking, CD40 ligation and dendritic-cell-derived $\mathrm{B}$ cell activating factors such as BAFF and APRIL [6, 11]. Additionally, CpG ODN seems to require cooperative stimulation from CD40L (CD154) or signals from plasmacytoid dendritic cells to induce cytokines such as IL- 6 and IL-10 in B cells. There seem to be substantial species-specific differences with respect to innate responses of $\mathrm{B}$ cells stimulated with CpG ODN. In mice, all subtypes of B cells seem to be directly activated by CpG ODN whereas in humans, direct activation occurs mainly in activated and memory B cells from blood.

We recently reported a novel $B$ cell population with regulatory functions $\left(\mathrm{B}_{\text {regs }}\right)$ in sheep Peyer's patches $(\mathrm{PP})$. These PP $B_{\text {regs }}$ suppress IFN- $\alpha$, IFN- $\gamma$ and IL-12 primarily through IL-10 and possibly other mechanisms [12]. However, how TLR responses are regulated in these $B_{\text {regs }}$ has not been explored. The objectives of the present investigations were to determine whether $\mathrm{CpG}$ ODN can induce innate immune responses in $\mathrm{PP} \mathrm{B}_{\text {regs }}$ and to examine how these responses are regulated. Investigations at the level of both biological responses and phosphorylation-mediated signal transduction indicate that $B_{\text {regs }}$ do not respond to stimulation with the TLR9 agonist CpG ODN.

\section{Materials and Methods}

\section{Oligonucleotides}

The sequences of the $3 \mathrm{ODN}$ used in this study have been published [12]. B class (2007) CpG ODN was obtained from Merial SAS Ltd. (Lyon, France), C class (2429) from Coley Pharmaceutical Group (Wellesley, Mass., USA) and control non-CpG ODN GpC 2007 was purchased from Operon (Alameda, Calif., USA). Synthetic single-strand RNA oligoribonucleotide (ORN) 1075 was obtained from Coley Pharmaceutical Group (Ottawa, Ont., Canada).
Animals

Suffolk sheep of either sex (3-4 months of age) were obtained from the Department of Poultry and Animal Science (University of Saskatchewan, Saskatoon, Sask., Canada) and were housed at the Vaccine and Infectious Disease Organization animal facility. All experiments were carried out according to the Guide to the Care and Use of Experimental Animals, provided by the Canadian Council on Animal Care. Experimental protocols were approved by the University of Saskatchewan Animal Care Committee.

Isolation of Peripheral Blood Mononuclear Cells, Jejunal PP and Lymph Node Cells

Blood was collected from the jugular vein of sheep in ethylenediamine-tetraacetic-acid (EDTA)-treated vacutainer tubes (BD Biosciences, Mountain View, Calif., USA), and peripheral blood mononuclear cells (PBMC) were isolated using 54\% isotonic Per$\operatorname{coll}^{\circledR}$ (Pharmacia Biotech AB, Uppsala, Sweden), as described previously [13].

Sheep were humanely euthanized, and mesenteric lymph nodes (mLN) and jejunal PP (JPP) were collected and cells isolated as described before [14]. The number of viable cells was determined by trypan blue dye exclusion and counting in a hemocytometer under a light microscope. Cells were resuspended in AIM V ${ }^{\circledR}$ medium containing $2 \%$ fetal bovine serum. For magnetic activated cell sorting $\left(\mathrm{MACS}^{\circledR}\right)$ isolation, cells were resuspended in MACS buffer [phosphate-buffered saline (PBS), EDTA and $10 \%$ bovine serum albumin].

\section{Tissue Culture Conditions}

Stimulation of PBMC, JPP and mLN cells was performed in 96-well, round-bottom plates (Nunc, Naperville, Ill., USA) using AIM V medium supplemented with $2 \%$ fetal bovine serum, 100 $\mathrm{IU} / \mathrm{ml}$ penicillin, $100 \mu \mathrm{g} / \mathrm{ml}$ streptomycin sulfate, $0.25 \mu \mathrm{g} / \mathrm{ml} \mathrm{am}$ photericin B, $2 \mathrm{mM}$ L-glutamine, $50 \mu \mathrm{M} 2$-mercaptoethanol and $10 \mu \mathrm{g} / \mathrm{ml}$ polymyxin B sulfate (Sigma-Aldrich) as described before [12]. For each treatment, $5 \times 10^{5}$ cells were cultured in triplicate wells in $200 \mu \mathrm{l}$ total volume. Culture supernatants were harvested and stored at $-20^{\circ} \mathrm{C}$ until assayed for IL-10, IL-12 and IgM.

\section{Enzyme-Linked Immunosorbent Assay for IL-10, IL-12 and $\operatorname{IgM}$}

ELISA for quantifying cytokines in cell culture supernatants were performed as previously reported for IL-12 [15] and IL-10 [16]. For IgM ELISA, serum was diluted using PBS with $0.05 \%$ Tween ${ }^{\circledR} 20$, and positive controls (sheep pre-bleed serum) were serially diluted $(1 / 10,1 / 100,1 / 1,000$ etc.) while supernatants were serially diluted 3 -fold. Diluted samples were incubated for $2 \mathrm{~h}$ and then washed. The captured IgM antibodies were detected in one step using alkaline-phosphatase-labeled rabbit anti-sheep IgM antibody (KPL, Md., USA; cat.: 052303) and visualized using $p$ nitrophenyl phosphate.

\section{Cell Purification Using MACS}

The naive $B$ cell population was obtained by enriching for CD21+ B cells. Routinely, purified cells were $>94 \%$ pure for the CD21+ cell population as assessed by flow cytometry. The CD21+ $\mathrm{B}$ cell fraction of PBMC and JPP was isolated as previously described [12]. 
Caspase Assay

Caspase 3/7 enzyme activity was determined using the Caspase-Glo ${ }^{\circledR} 3 / 7$ assay (Promega, Madison, USA) according to the manufacturer's instructions. Briefly CD21+ B cells were isolated as described above and either cultured in media or stimulated with CpG ODN $(5 \mu \mathrm{g} / \mathrm{ml})$ or GpC $(5 \mu \mathrm{g} / \mathrm{ml})$. After 24 and $48 \mathrm{~h}$ of incubation, $100 \mu \mathrm{l}$ of Caspase-Glo 3/7 reagent was added to each well of a 96-well plate. Luminescence in each sample was measured using the plate-reading Luminometer (Victor ${ }^{3} \mathrm{~V}$, Perkin Elmer Inc., Calif., USA). Three independent experiments were performed.

\section{Lymphocyte Proliferative Responses}

Cells were resuspended in culture medium at $2.5 \times 10^{5}$ cells/ well in a final volume of $200 \mu$ l. Triplicate cultures were stimulated and incubated as already described above. During the final $6 \mathrm{~h}$ of the 72-hour incubation, cells were pulsed with $0.4 \mu \mathrm{Ci}^{3} \mathrm{H}$-thymidine (Amersham Pharmacia, Piscataway, N.J., USA). Cells were harvested using standard liquid scintillation protocols, and uptake of ${ }^{3} \mathrm{H}$-thymidine was assessed in a beta counter (Topcount, Packard Instrument Company, Meriden, Conn., USA). Cell proliferation was calculated as the mean counts per minute of triplicate cultures and expressed as a stimulation index (counts per minute in the presence of stimulus/counts per minute in the absence of stimulus). For the lymphocyte proliferation response assay, a $\gamma$-irradiated cell line expressing murine CD40 ligand (CD154), a known ovine B cell mitogen [17], was added at a 1:10 ratio to confirm that B cells in enriched cultures were capable of a proliferative response.

\section{Quantitative RT-PCR}

RT-PCR was used to quantify TLR9 mRNA in the JPP (CD21+ and CD21-) and PBMC (CD21+ and CD21-) population as described previously [18]. Samples were normalized internally using the average cycle threshold (Ct) of $\beta$-actin as a reference. Values were expressed as $\Delta \mathrm{Ct}$ value per $500 \mathrm{ng}$ total input RNA.

\section{Western Blot}

CD21+ B cells $\left(1 \times 10^{7}\right)$ isolated from JPP and PBMC were lysed, and the protein level was measured. Western blots were performed using $30 \mu \mathrm{g}$ protein and probed with anti-human TLR9 antibody (IMG-305A; Imgenex, San Diego, USA).

\section{Kinome Analysis}

A description of the rationale and process of construction of the bovine specific peptide arrays for kinome analysis has been presented elsewhere [19]. Briefly, peptides were selected to represent phosphorylation events associated with a spectrum of cellular events but with emphasis on responses associated with innate immunity. Bovine consensus sequences of the human and mouse peptides selected from Phosphosite were obtained by employing the Blastp program from NCBI to compare collected human peptides against the NCBI bovine protein database. Blastp was set to retrieve short exact matches. Parsed Blastp ${ }^{\mathrm{SM}}$ results revealed that the majority of the hit sequences had $100 \%$ identity to their query sequences, and a comparison of the protein descriptions for the query and hit sequences confirmed that they referred to the same protein. Similarly, we used Blastp ${ }^{\mathrm{SM}}$ to determine whether the array was also ovine specific. Analysis of the 16 peptide sequences by Blastp ${ }^{\mathrm{SM}}$ revealed that they are the same protein in sheep (data not shown).

Isolated purified CD21+ B cells $\left(25 \times 10^{6}\right)$ from JPP and PBMC were stimulated with medium alone or $5 \mu \mathrm{g} / \mathrm{ml}$ of 2429
CpG ODN for 4 h at $37^{\circ} \mathrm{C}$ and $5 \% \mathrm{CO}_{2}$ and $95 \%$ humidity. Cells were pelleted and stored at $-80^{\circ} \mathrm{C}$ before use with the peptide arrays. Cell lysate was prepared and incubated with the arrays as reported previously with the exception that lysates from $25 \times 10^{6}$ CD21+ B cells were incubated with each chip (10). Briefly, cell pellets were lysed with $100 \mu$ l lysis buffer $(20 \mathrm{mM}$ Tris-HCl, $\mathrm{pH}$ 7.5, $150 \mathrm{mM} \mathrm{NaCl}, 1 \mathrm{~mm}$ EDTA, $1 \mathrm{~mm}$ ethylene glycol tetraacetic acid, $1 \%$ Triton, $2.5 \mathrm{mM}$ sodium pyrophosphate, $1 \mathrm{mM} \mathrm{Na}_{3} \mathrm{VO}_{4}, 1 \mathrm{mM}$ $\mathrm{NaF}, 1 \mu \mathrm{g} / \mathrm{ml}$ leupeptin, $1 \mu \mathrm{g} / \mathrm{ml}$ aprotinin, $1 \mathrm{~mm}$ phenylmethylsulfonyl fluoride), incubated on ice for $10 \mathrm{~min}$ and then spun in a microcentrifuge for $10 \mathrm{~min}$ at $4^{\circ} \mathrm{C}$. A $70-\mu l$ aliquot of this supernatant was mixed with $10 \mu \mathrm{l}$ of the activation mix (50\% glycerol, $50 \mu \mathrm{M}$ ATP, $60 \mathrm{mM} \mathrm{MgCl}_{2}, 0.05 \% \mathrm{v} / \mathrm{v}$ Brij-35 and $0.25 \mathrm{mg} / \mathrm{ml}$ bovine serum albumin) and incubated on the chip for $2 \mathrm{~h}$ at $37^{\circ} \mathrm{C}$. Finally, slides were washed once with Tris-buffered saline (PBS; $1 \times$ solution; $\mathrm{pH} 7.3$ ) containing $1 \%$ Triton ${ }^{\circledR} \mathrm{X}-100$, twice with $2 \mathrm{M}$ $\mathrm{NaCl}$ containing $1 \%$ Triton $\mathrm{X}-100$ and in demineralized $\mathrm{H}_{2} \mathrm{O}$. Phosphoprotein-specific stain peptide arrays were performed. Following incubation, slides were washed once in PBS-Triton, then submerged in stain $\left(\mathrm{PRO}-\mathrm{Q}^{\circledR}\right.$ Diamond Phosphoprotein Stain, Invitrogen) with agitation for $1 \mathrm{~h}$. Arrays were then washed in tubes containing destain [20\% acetonitrile (EMD Biosciences, VWR distributor, Mississauga, Ont., Canada) and $50 \mathrm{~mm}$ sodium acetate (Sigma) at $\mathrm{pH} 4.0$ ] for $10 \mathrm{~min} 3$ times with the addition of destain each time. A final wash was done with distilled water. Arrays were dried and read using a Genepix ${ }^{\circledR}$ professional 4200A microarray scanner (MDS Analytical Technologies, Toronto, Ont., Canada) at 532-560 nm with a 580-nm filter to detect dye fluorescence. Images were collected using the Genepix 6.0 software (MDS). Images were then loaded on Arrayvision ${ }^{\circledR}$ (Image Research Inc). Intensity values for the spots and background were obtained, and normalization (80th percentile per chip) and statistical analyses were performed with Genespring ${ }^{\circledR}$ (Agilent Technologies) software. We used 4 biological replicates, and each slide contained a triplicate array. The results were shown as n-fold change in phosphorylation and measured relative to the respective unstimulated CD21+ B cells.

\section{Statistical Analysis}

Data was analyzed using the statistical software Graphpad Prism $^{\text {TM }} 5$ (Graphpad, San Diego, Calif., USA). Statistical differences in median values between two groups were determined using the Kruskal-Wallis test, and comparisons were done between groups using Dunn's multiple comparison test. Values of $\mathrm{p}<0.05$ were considered significant.

\section{Results}

\section{PP Cells Proliferate Poorly in Response to CPG ODN Stimulation}

We evaluated lymphocyte proliferative responses in Peyer's patches (ileal PP and JPP) stimulated with CpG ODN and compared responses to those in mLN and PBMC. Both PBMC and mLN exhibited significantly higher proliferative responses $(\mathrm{p}<0.05)$ compared to JPP (fig. 1) and ileal PP (data not shown). Of note, the prolif- 
Fig. 1. Lymphocyte proliferative responses in ovine JPP, PBMC and mLN cells following stimulation with $2.0 \mu \mathrm{g} / \mathrm{ml}$ of $\mathrm{CpG}$ ODN. Data represent individual values for each animal $(\mathrm{n}=11)$, and horizontal bars show the mean value for each group. Significant differences $(\mathrm{p}<0.05)$ relative to JPP are represented by a boxed asterisk. Boxed double asterisks represent the significant difference $(\mathrm{p}<0.05)$ relative to all the other tissues.
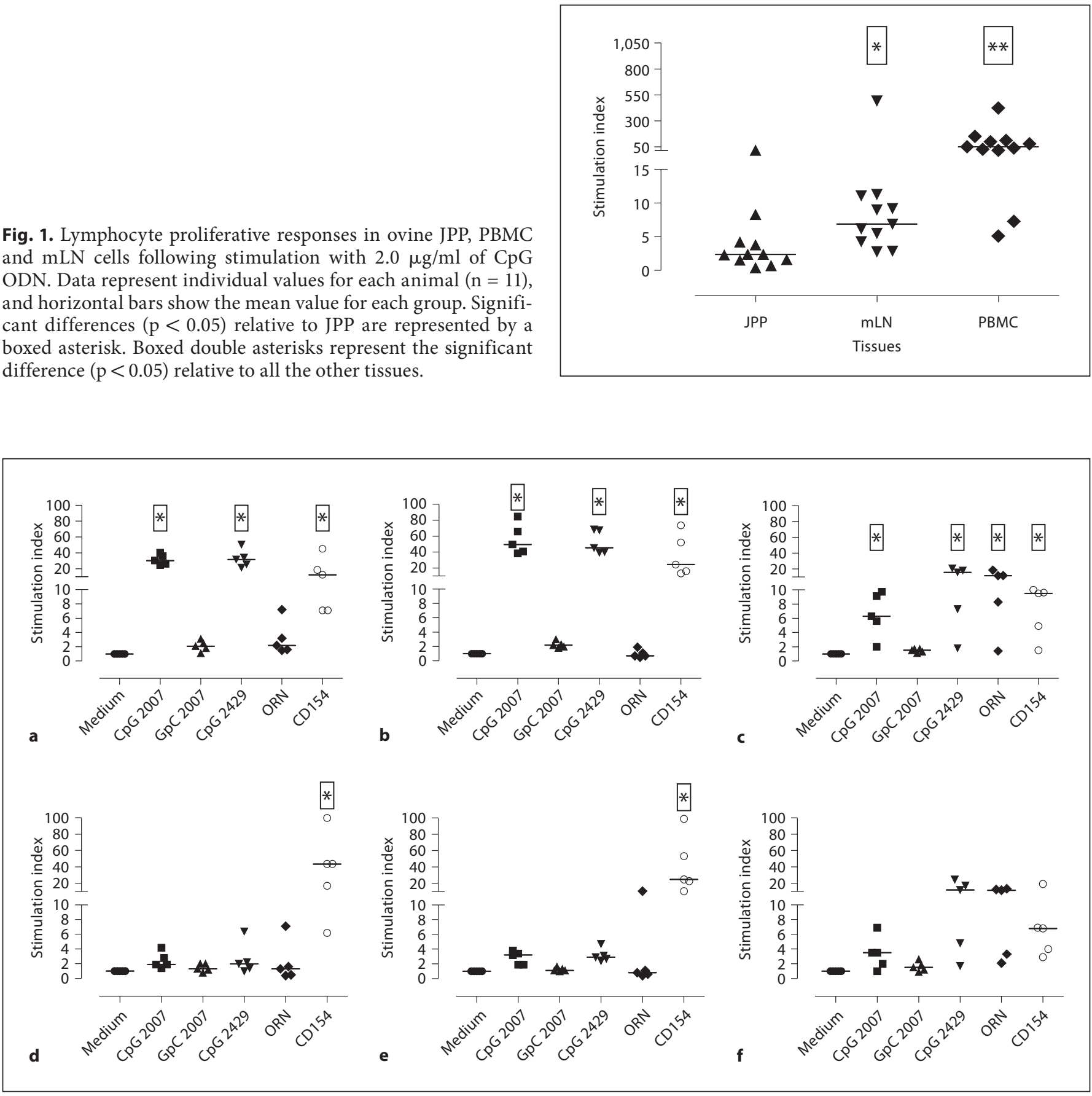

Fig. 2. Lymphocyte proliferative responses in ovine PBMC, JPP and their respective MACS-purified CD21+ B cell and CD21- cell populations following stimulation with either $5 \mu \mathrm{g} / \mathrm{ml}$ of $\mathrm{CpG}$ 2007, CpG 2429, ORN, CD154, control GpC 2007 or medium alone. Values from individual animals are presented, and means are indicated by horizontal bars for each treatment group $(n=5)$. Significant differences $(\mathrm{p}<0.05)$ in treatments relative to $\mathrm{GpC}$ controls are indicated by a boxed asterisk. a PBMC. b CD21+ PBMC. c CD21- PBMC. d JPP. e CD21+ JPP. f CD21- JPP. 

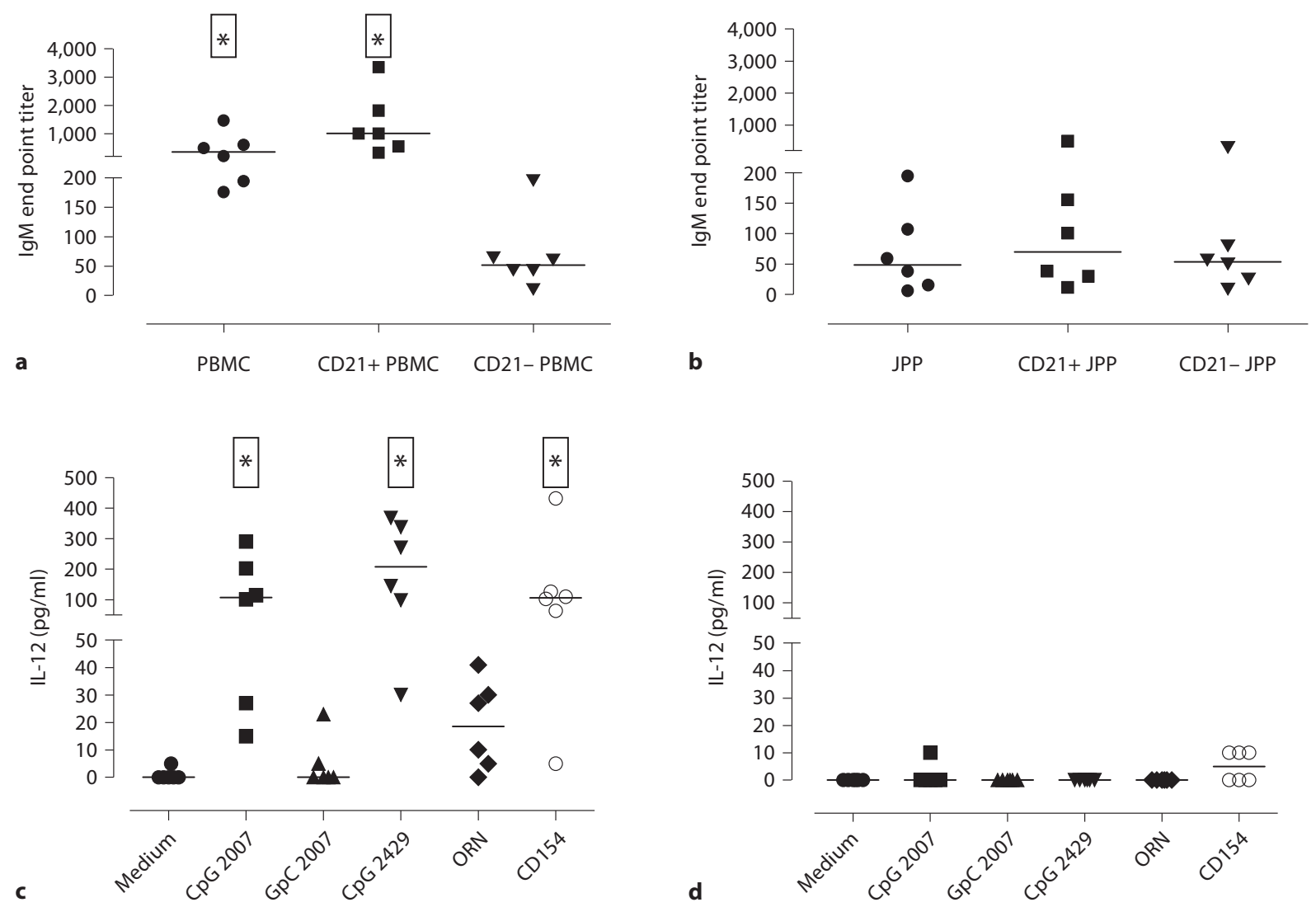

Fig. 3. a, b IgM responses in ovine PBMC, JPP, MACS-purified CD21+ B and CD21- cell populations from both tissues following stimulation with $5 \mu \mathrm{g} / \mathrm{ml}$ of CpG ODN 2429. Values from individual animals are presented, and means are indicated by a horizontal bar for each treatment group $(n=6)$. Significant differences $(p<0.05)$ in treatments relative to the CD21- cell population are indicated by a boxed asterisk. c, $\mathbf{d}$ IL-12 responses in the purified CD21+ B cell population from PBMC (c) and JPP (d) following stimulation with either $5 \mu \mathrm{g} / \mathrm{ml}$ of CpG 2007, CpG 2429, ORN, CD154, control GpC 2007 or medium alone. Values from individual animals are presented, and means are indicated by a horizontal bar for each treatment group $(n=6)$. Significant differences $(\mathrm{p}<0.05)$ in treatments relative to $\mathrm{GpC}$ controls are indicated by a boxed asterisk. erative responses in PBMC were significantly higher than in $\mathrm{mLN}$.

Furthermore, we performed a dose titration experiment using CpG ODN doses of 0.66, 2.0, 6.0 and $18.0 \mu \mathrm{g} /$ $\mathrm{ml}$. We found that the poor proliferative responses in PP following stimulation with $\mathrm{CpG}$ ODN were not due to suboptimal concentrations of the ODN or to the classes of CpG ODN (data not shown).

In humans, subpopulations of B cells (naïve, activated and memory) have been reported to respond differently to TLR9 activation in blood $[6,20]$. In the present study, blood CD21+ B cells isolated from sheep were highly proliferative when stimulated with both classes of $\mathrm{CpG}$ ODN (fig. 2a, b) but the CD21- population had a much lower proliferation response (fig. 2c). In contrast, $\mathrm{CpG}$ ODN did not induce any significant proliferative responses in purified CD21+ B cells from $\mathrm{PP}$ (fig. 2e). Therefore, CD21+ B cells from blood and PP behave quite differently with respect to their proliferative responses to CpG ODN stimulation. However, CD154 induced significant proliferation on PP CD21+ B cells, indicating that these cells were viable and have a proliferative capacity when appropriately stimulated. Interestingly, the CD21population in PP had a higher proliferative response upon 
Fig. 4. IL-10 responses in purified CD21+ B cell populations from JPP (a) and PBMC (b) following stimulation with either $5 \mu \mathrm{g} /$ ml of CpG 2429, CD154, control GpC 2007 or medium alone. The graph represents means \pm SEM for each treatment group $(\mathrm{n}=6)$.

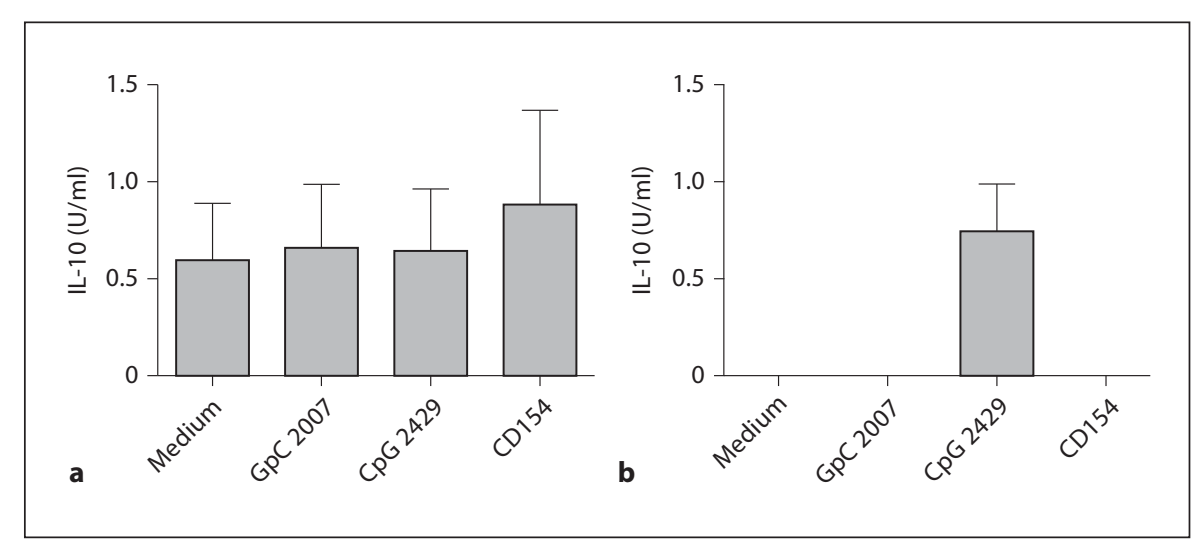

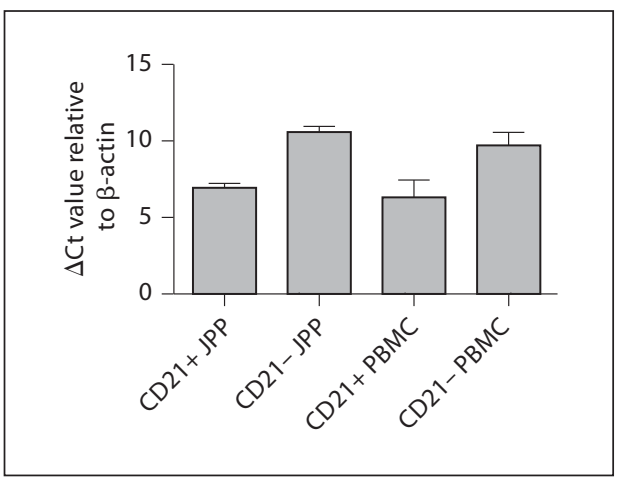

Fig. 5. TLR9 mRNA expression in CD21+ B cells isolated by MACS from PBMC and JPP. The value represents the expression of TLR9 compared to $\beta$-actin. Bars represent the average expression $(\Delta \mathrm{Ct})$ for each cell population.

stimulation by CpG ODN (fig. 2f). This observation suggests that CD21+ B cells may downregulate CpG-induced proliferation in PP cells.

\section{PP CD21+ B Cells Fail to Secrete Significant IgM}

Levels upon $C P G$ ODN Stimulation

B cells also produce polyclonal IgM antibody upon stimulation with CpG ODN [8]. We therefore assessed whether PP CD21+ B cells secreted IgM in response to CpG ODN stimulation, and compared these responses to CD21+ B cells from blood. As expected, PBMC secrete significant levels of IgM when stimulated with CpG ODN (fig. 3a). Purified blood CD21+ B cells secreted high levels of IgM in response to $\mathrm{CpG}$ ODN stimulation but no significant IgM production was observed in the CD21- cell fraction (fig. 3a). In contrast, the mixed population of PP cells did not produce any significant IgM upon stimula- tion with CpG ODN (fig. 3b). Neither CD21+ nor the CD21- cell fractions from the PP produced significant IgM responses following stimulation with CpG ODN (fig. 3b). Thus, unlike CD21+ B cells isolated from blood, CD21+ B cells isolated from JPP did not secrete IgM when stimulated with CpG ODN.

\section{CD21+ B Cells from Blood but Not CD21+B Cells}

\section{from JPP Secrete IL-12}

$B$ cells are known mainly for the production of antibodies but they can also secrete a variety of cytokines including IL-12 when stimulated with TLR agonists or under inflammatory conditions. For example, human and murine B cells secrete high levels of IL-12 when stimulated with CpG ODN and CD154 [21]. Thus, we wondered whether CD21+ B cells were capable of secreting IL-12 upon either CpG ODN or CD154 stimulation. Purified PP CD21+ B cells did not secrete IL-12 upon stimulation with either CpG ODN (C and B class), ORN (TLR7/8 agonists) or CD154 (fig. 3d). However, purified blood CD21+ B cells secreted high levels of IL-12 in response to stimulation by CpG ODN, ORN and CD154 (fig. 3c).

\section{PP CD21+ B Cells Spontaneously Secrete IL-10}

We assessed the ability of PP and blood CD21+ B cells to produce IL-10 in the presence or absence of $\mathrm{CpG}$ ODN stimulation. As shown in figure $4 \mathrm{a}$, unstimulated PP CD21+ B cells secreted IL-10 and stimulation of these cells with CpG ODN, control GpC or with CD154 did not result in any additional increase in IL-10 production. In contrast, blood CD21+ B cells produced IL-10 only after stimulation with CpG ODN (fig. 4b).

Thus, although PP CD21+ B cells fail to proliferate or secrete IgM and IL-12 when stimulated with CpG ODN, they spontaneously secrete IL-10. 
Fig. 6. Levels of caspase $3 / 7$ in purified CD21+ B cell populations from JPP (a) and PBMC (b) following stimulation with $5 \mathrm{mg} / \mathrm{ml}$ of CpG 2429, control GpC 2007 or medium control. CPS $=$ Counts per second. The graph represents means \pm SEM for each treatment group $(n=4-6)$.

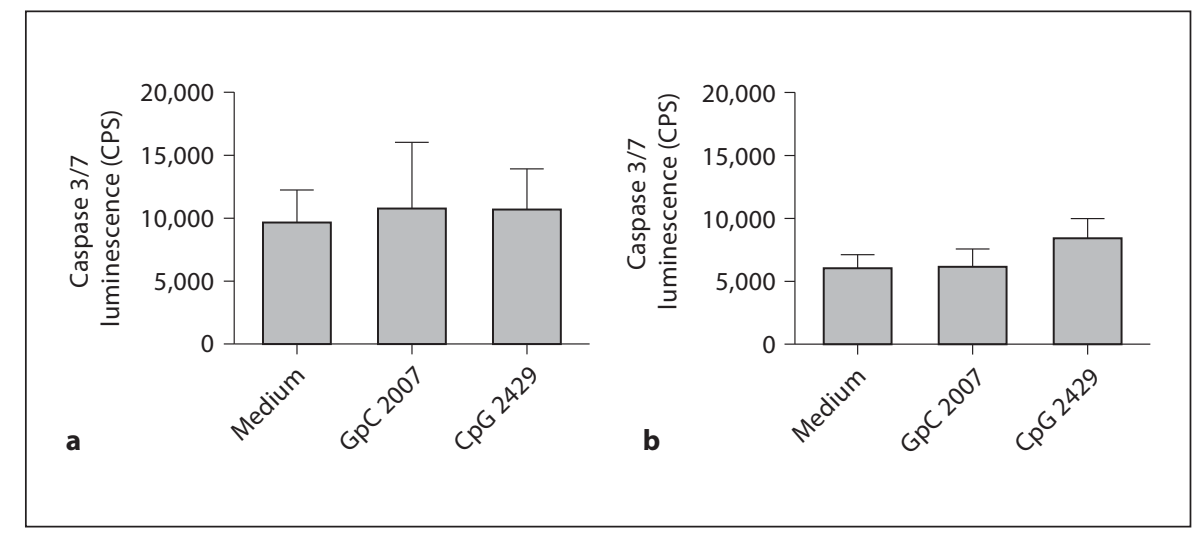

\section{PP CD21+ B Cells Express TLR9 Receptor}

A major requirement for $\mathrm{CpG}$ ODN stimulation is the presence of its receptor, TLR9. We wondered whether the poor responsiveness of PP CD21+ B cells to the CpG stimulation was due to a lack of TLR9 expression. Therefore we evaluated the expression of TLR9 in both PP and PBMC CD21+ B cells using quantitative PCR.

Both PP CD21+ and blood CD21+ B cells expressed similar levels of TLR9 mRNA, and as expected, the CD21+ fractions expressed higher levels of TLR9 transcripts than the CD21- fractions (fig. 5). Moreover, this was confirmed by assessing the level of TLR9 protein in CD21+ B cells from JPP and PBMC using Western blot and found that the expression level of the TLR9 protein was similar in both cell types (data not shown). Thus, the poor responses of PP CD21+ B cells to CpG ODN stimulation may not be due to the lack of TLR9 receptor.

Unresponsiveness of PP CD21+B Cells to CPG ODN Is Not due to Apoptosis or IL-10

One possible outcome of CpG ODN stimulation in B cells is the induction of programmed cell death (apoptosis). Therefore we evaluated whether stimulation of JPP CD21+ B cells with CpG ODN induced apoptosis which could result in an apparent unresponsiveness. We observed similar levels of caspase $3 / 7$ in both CD21+ B cells from blood and JPP following 24-hour stimulation by CpG ODN or its control GpC (fig. 6a, b). Therefore programmed cell death is unlikely to be the cause of the poor responses in JPP CD21+ B cells stimulated with CpG ODN.

Another potential cause of PP CD21+ B cell failure to respond to $\mathrm{CpG}$ stimulation may be the influence of antiinflammatory cytokines such as IL-10 and TGF- $\beta$. As reported previously [12], unstimulated purified CD21+ B cells from PP spontaneously secrete IL-10, which suppressed CpG-induced innate immune responses. Therefore we tested whether neutralization of IL-10 had any effect on CpG-induced responses in PP CD21+ B cells. Neutralization of IL-10 in PP CD21+ B cell cultures did not result in any significant increases in proliferation following stimulation with CpG ODN (fig. 7a, b). Thus, the unresponsiveness of PP CD21+ B cells following $\mathrm{CpG}$ ODN stimulation is not due to suppression by IL-10.

\section{Failure of TLR9 Signaling in PP CD21+ B Cells}

Although CD21+ B cells from blood and JPP express similar levels of TLR9, there was a marked difference in $\mathrm{B}$ cell responses to CpG ODN stimulation. The seeming presence of the TLR9 receptor on both cell types suggests that the differential responses of these two cell types to CpG stimulation reflect unique patterns of signal transduction. To investigate this potential mechanism, kinome analysis was utilized to quantify levels of activity of kinases known to be activated in the TLR9 pathway. Both blood and PP CD21+ B cells, with and without stimulation by CpG ODN, were examined. PP and blood CD21+ $B$ cells showed marked differences in their overall signal patterns as well as numerous differences specific to TLR signaling. Table 1 summarizes $n$-fold changes in phosphorylation of CpG-induced CD21+ B cells from PP and blood (PBMC) relative to their unstimulated controls. Sixteen out of the 300 peptides on the array revealed contrasting $\mathrm{n}$-fold changes in phosphorylation when $\mathrm{PP}$ CD21+ B cells were compared to blood CD21+ B cells. Activation of TAK1 depends on the phosphorylation of a series of C-terminal sites including Ser192 [36, 37]. This kinase target underwent a 70 -fold increase in phosphorylation (orange color, fig. 8a) in CD21+ B cells from PBMC upon $\mathrm{CpG}$ ODN stimulation. In contrast, $\mathrm{CpG}$ stimula- 


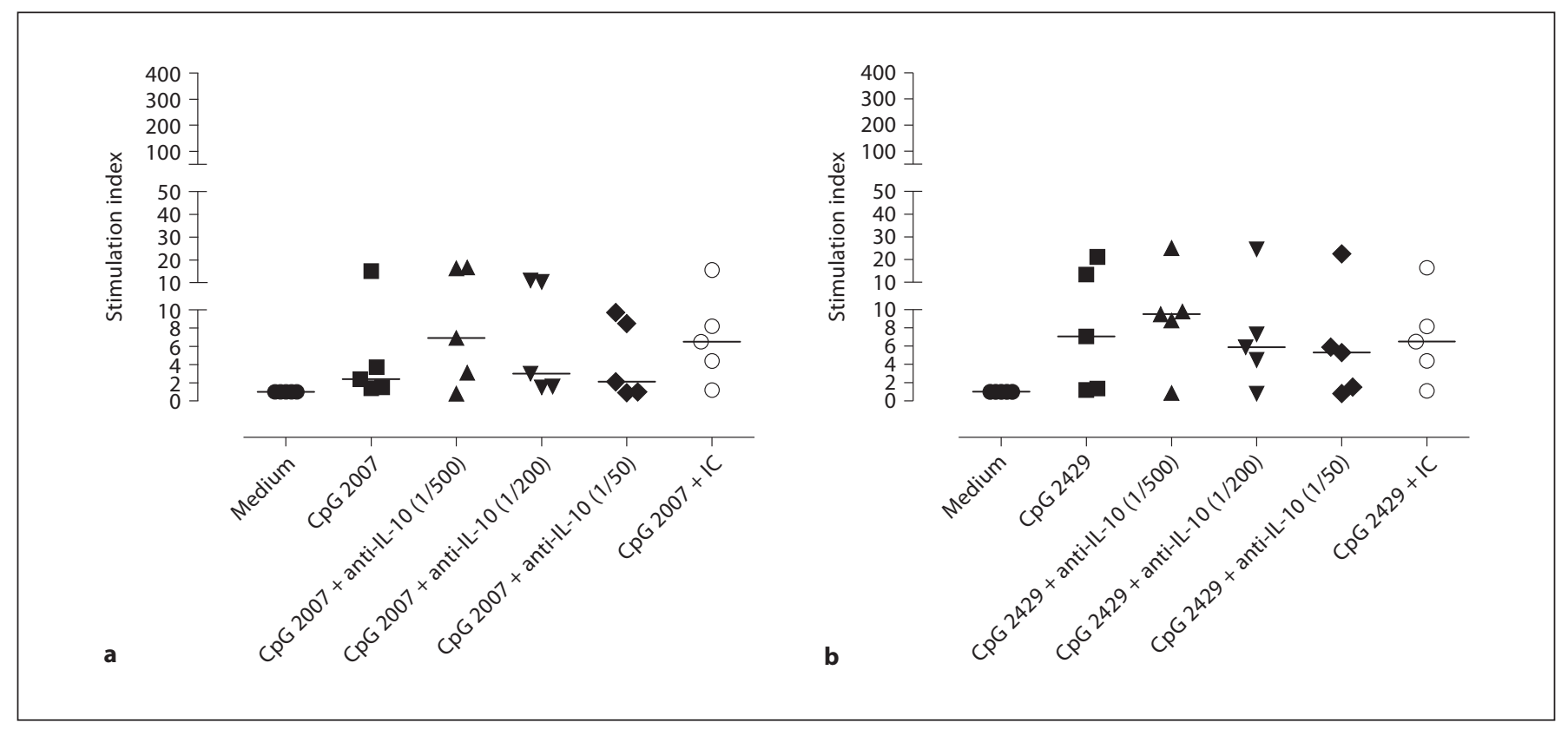

Fig. 7. Lymphocyte proliferation responses in purified CD21+ B cell populations from JPP following incubation in the presence or absence of increasing concentrations of anti-IL-10 antibody, and subsequently stimulated with CpG 2007 (a) or 2429 (b). Values for

Table 1. Peptides representing TLR adaptor molecules on the kinase array with targeted phosphorylation sites

\begin{tabular}{|c|c|c|c|c|}
\hline $\begin{array}{l}\text { TLR adaptor } \\
\text { proteins }\end{array}$ & $\begin{array}{l}\text { Target ami- } \\
\text { no acid on } \\
\text { the protein }\end{array}$ & $\begin{array}{l}\text { JPP CD21+ } \\
\text { CpG n-fold } \\
\text { change }\end{array}$ & $\begin{array}{l}\text { PBMC CD21+ } \\
\text { CpG n-fold } \\
\text { change }\end{array}$ & $\begin{array}{l}\text { Effect of phos- } \\
\text { phorylation on } \\
\text { target peptide }\end{array}$ \\
\hline IKK- $\alpha$ & $\mathrm{T} 23$ & -4.43 & 46 & activation [22] \\
\hline Fos & $\mathrm{T} 232$ & -113.6 & 2.13 & activation [23] \\
\hline IKK- $\beta$ & Y199 & 54.2 & 1 & activation $[24]$ \\
\hline TAK1 & S192 & -67.37 & 72.2 & activation [25] \\
\hline p38- $\alpha$ & Y323 & -136.47 & 100.2 & activation [26] \\
\hline JNK1 & S377 & -26.9 & 88.23 & activation [27] \\
\hline NF-кB-p65 & S276 & 1.02 & 5.25 & activation [28] \\
\hline NF-кB-p65 & S311 & -1.28 & 3.31 & tion [29] \\
\hline NF-кB-p65 & S536 & 1.09 & 3.61 & activation [30] \\
\hline IRAK1 & $\mathrm{T} 100$ & 3.51 & 1.03 & inhibition [31] \\
\hline IRAK1 & T387 & -3.82 & 9.11 & activation [32] \\
\hline FADD & S194 & -29.23 & -1.36 & activation [33] \\
\hline Casp8 & S347 & -6.18 & 4.34 & inhibition [34] \\
\hline PKACa & $\mathrm{T} 195 / 7$ & -7.76 & 3.62 & activation [27] \\
\hline PKACa & S338 & -6.27 & 1.12 & activation [35] \\
\hline
\end{tabular}

Data represent $\mathrm{n}$-fold change in phosphorylation of CpG-induced CD21+ B cells from JPP and PBMC relative to their respective cells cultured in medium alone. In this table, relative phosphorylation levels (CpG-stimulated CD21+ B cell lysates/medium-cultured CD21+ B cell lysates) and their effect on the peptide targets are reported. References are shown in brackets. individual animals are presented, and means are indicated by a horizontal bar for each treatment group $(n=5)$. IC = Isotype control.

tion of PP CD21+ B cells induced a decrease (50-fold) in phosphorylation (mauve color, fig. $8 \mathrm{~b}$ ) of the same kinase target (table 1). Activation of IKK- $\alpha$ also depends on phosphorylation of the amino acid Thr23 [22]. We found that upon CpG stimulation of blood CD21+ B cells, this IKK- $\alpha$ target site had a 46 -fold increase in phosphorylation (orange color, fig. 8a) but stimulation of PP CD21+ B cells with CpG resulted in a 4.4 -fold decrease in phosphorylation (pink color, fig. 8b) of this peptide. Activation of p-38- $\alpha$ kinase depends on phosphorylation of target sites including Tyr323 [26]. Upon CpG stimulation of blood CD21+ B cells, this target underwent a 100-fold increase in phosphorylation (orange color, fig. 8a), whereas PP CD21+ B cells underwent a 136-fold decrease in phosphorylation (red color, fig. 8b) upon CpG stimulation. Similarly, JNK1 (S377), NF-кB-p65 (S311, S276 and S536), FADD (S194), Casp8 (S347), PKACa (T195/7) and Fos (Thr232) have been shown to be activated when their respective targets are phosphorylated [27, 34, 38, 39]. We found that in blood CD21+ B cells, all these targets displayed increased phosphorylation following stimulation with CpG ODN while in PP CD21+ B cells, all those targets displayed decreased $n$-fold changes in phosphorylation. The enzymatic activities of IRAK1 have been shown to be regulated differentially, that is phosphorylation of 


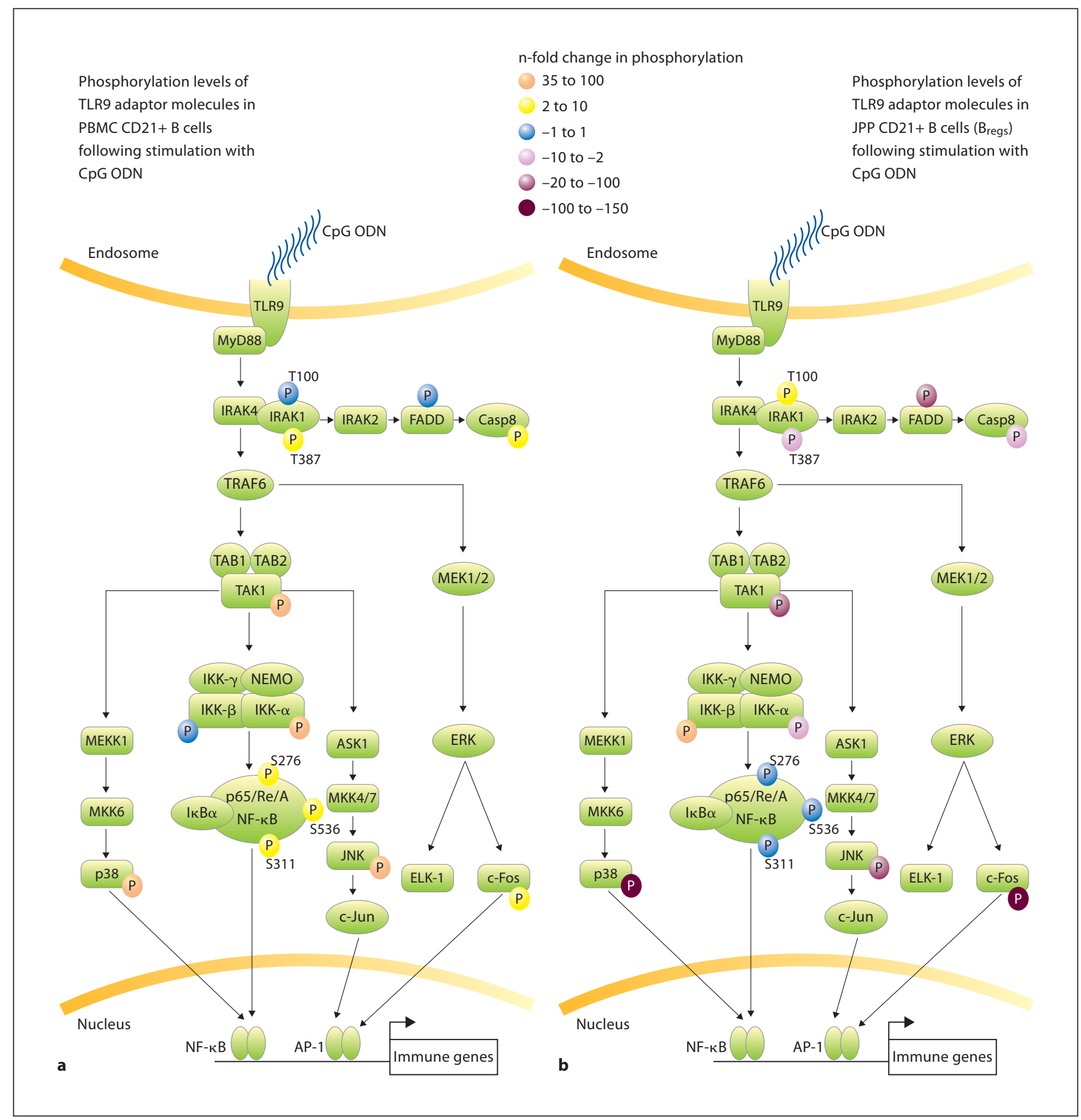

Fig. 8. a Following stimulation with CpG ODN, blood CD21+ B cell lysates had increased the n-fold change in phosphorylation of IRAK1, FADD, Casp8, TAK1, p38, IKK- $\alpha$, JNK and Fos (yellow to orange) leading to activation of the NF- $\kappa$ B and AP-1 and MAPK pathways. No change in $n$-fold change in phosphorylation is represented by the blue color. b Upon stimulation with $\mathrm{CpG}$

ODN, PP $B_{\text {regs }}(\mathrm{CD} 21+)$ cell lysates had decreased the $\mathrm{n}$-fold change in phosphorylation of IRAK1, FADD, Casp8, TAK1, p38, IKK- $\alpha$, JNK and Fos (pink to red) upon stimulation with CpG ODN. The $\mathrm{n}$-fold changes were relative to their respective medium culture cell lysates. The range for the color is given in the color legend. 
the T387 target site resulted in activation of the enzyme [32] while phosphorylation of the T100 target site resulted in inhibition of IRAK1 [31]. In blood CD21+ B cells, we observed that IRAK1 (T387) had a 9-fold increase in phosphorylation (yellow color, fig. 8a) while in PP CD21+ $\mathrm{B}$ cells, we found a 3.8-fold decrease in phosphorylation of IRAK1 (T387) following CpG stimulation (pink color, fig.8b). Interestingly, we observed in blood CD21+ B cells that the inhibitory IRAK1 site T100 was unchanged in phosphorylation $n$-fold change (blue color, fig. 8a) while in PP CD21+ B cells, IRAK1 (T100) displayed a 3.5-fold increase in phosphorylation (yellow color, fig. 8b) upon stimulation with CpG ODN. As summarized in colorcoded figure $8 \mathrm{a}$ and $\mathrm{b}$, all of the above adaptor molecules are involved in the TLR9 pathway but they display differential phosphorylation n-fold changes in PP compared to blood CD21+ B cells upon stimulation by CpG ODN. These results demonstrate that the key adaptor molecules for TLR9 signaling transduction leading to NF- $\kappa \mathrm{B}, \mathrm{AP}-1$ and MAPK pathway activation are dysfunctional in $\mathrm{PP}$ CD21+ B cells compared to blood CD21+ B cells following stimulation with CpG ODN.

\section{Discussion}

We previously observed that $\mathrm{PP} \mathrm{B}_{\text {regs }}$ have regulatory activity and downregulate TLR9-induced IFN- $\alpha$, IFN- $\gamma$ and IL-12 responses, and this suppression is mediated at least in part through IL-10 [12]. However, it is not known whether $B_{\text {regs }}$ respond to stimulation with the TLR9 agonist $\mathrm{CpG}$ ODN. In the present study, we demonstrated that PP $\mathrm{B}_{\text {regs }}$ failed to proliferate, secrete IgM and produce IL-12 following CpG ODN stimulation.

We investigated several potential mechanisms which may mediate the unresponsiveness of PP CD21+ B cells $\left(\mathrm{B}_{\text {regs }}\right)$ to stimulation with $\mathrm{CpG}$ ODN. The failure of $\mathrm{B}_{\text {regs }}$ to respond to CpG ODN was not due to a lack of TLR9 expression, CpG ODN activation-induced apoptosis or autocrine IL-10 regulation. However, CpG ODN unresponsiveness was not due to a lack of proliferative capacity in $\mathrm{PP} \mathrm{B}_{\text {regs }}$, since vigorous proliferation was observed when these cells were stimulated with CD154 (a T cell signal). Thus, $B_{\text {regs }}$ have the capacity to proliferate when appropriately stimulated.

PP $B_{\text {regs }}$ demonstrated the hallmarks of the described $\mathrm{B}$ regulatory cells [40] as they exclusively produced IL-10 but not IL-12 even when stimulated with CpG ODN, ORN or CD154. Moreover, we demonstrated another regulatory aspect of $B_{\text {regs }}$ as they suppress proliferation responses in other B cells. In this regard, depletion of $\mathrm{CD} 21+\mathrm{B}$ cells resulted in a significant increase in the proliferative responses of CD21- cell populations, presumably CD21- B cells. This result suggests that $\mathrm{PP}_{\mathrm{B}_{\text {regs }}}$ may regulate other $B$ cells but the mechanisms which mediate this regulation are not known.

TLR9 is a requisite for CpG-induced responses [3]. We have shown that $B_{\text {regs }}$ express similar levels of TLR9 mRNA and protein as blood CD21+ B cells, suggesting that TLR9 was not the cause of the unresponsiveness of PP $B_{\text {regs }}$ to $C p G$ stimulation. We then hypothesized that the failure of PP $B_{\text {regs }}$ to respond to TLR agonists may be due to differential regulation of phosphorylation events downstream of the TLR9 signaling pathway. Therefore we used kinome analysis to characterize TLR9 signaling in PP CD21+ B ( $\mathrm{B}_{\text {regs }}$ ) cells and blood CD21+ B cells. Interestingly, in blood CD21+ B cells which are highly responsive to TLR9 agonists, CpG ODN stimulation activates kinases such as IRAK1, TAK1, IKK $\alpha$, p38- $\alpha$, JNK1, FOS, NF-кB-p65, FADD, Casp8 and PKACa which are associated with TLR9-mediated signal transduction. In contrast, the above TLR adaptor molecules displayed a net decrease in phosphorylation in PP $\mathrm{B}_{\text {regs }}$ following $\mathrm{CpG}$ stimulation leading to dysfunction of these kinases associated with TLR9-mediated signal transduction. While IKK- $\beta$ appears the notable exception to this trend, it is important to consider that regulation of this protein involves phosphorylation events at numerous sites of the protein and that these modifications are catalyzed by a variety of kinases which are unrelated to TLR signaling.

It seems that stimulation of $\mathrm{PP} \mathrm{B}_{\text {regs }}$ by $\mathrm{CpG}$ ODN results in decreased phosphorylation of adaptor molecules early in the TLR9 pathway and causes inactivation of key adaptor molecules. Therefore, there must be regulatory mechanisms in $\mathrm{PP} \mathrm{B}_{\text {regs }}$ by which adaptor molecules are inactivated following ligand interaction with TLR9. Some key possible negative regulatory mechanisms in the TLR9 pathway that could be involved include: (i) factors that cause degradation of signal transduction molecules such as Triad3A (degrade specifically TLR4 and TLR9 receptor) [41], (ii) inhibition of adaptor molecules such as Src homology 2 domain-containing protein tyrosine phosphatase 1 (inhibit IRAK1) [42], (iii) deubiquitination of adaptor molecules by factors such as A20 and deubiquitinating enzyme A [43], (iv) differential cellular localization of TLR9 in different subsets of B cells which may require trafficking protein such as UNC93B1 and (vi) nonfunctional TLR9 receptor in PP CD21+ B cells.

In conclusion, $\mathrm{PP} \mathrm{B}_{\text {regs }}$ do not display biological responses to direct TLR9 stimulation despite expressing 
TLR9. However, kinome analysis confirms that TLR9 signaling did occur following CpG ODN stimulation. This response entailed differential signaling activity close to the receptor suggesting attenuation of both the primary and secondary TLR-induced signal transduction in PP $\mathrm{B}_{\text {regs. }}$. This raises important questions regarding the physiological role of the TLR9 receptor expression on this cell type.

\section{Acknowledgements}

We thank Sherry Tetland and Jan Erickson for assistance with care and management of animals. We also thank Jasnehta Permala for her assistance in preparing figure 8. Financial support was provided by grants from the Natural Science and Engineering Research Council, National Institutes of Health and Merial Ltd. This article is published with the permission of the director of Vaccine and Infectious Disease Organization as journal series No. 557.

\section{References}

$\checkmark 1$ Medzhitov R: Toll-like receptors and innate immunity. Nat Rev Immunol 2001;1:135-145.

- 2 Heil F, Hemmi H, Hochrein H, Ampenberger F, Kirschning C, Akira S, Lipford G, Wagner H, Bauer S: Species-specific recognition of single-stranded RNA via Toll-like receptor 7 and 8. Science 2004;303:1526-1529.

- 3 Hemmi H, Takeuchi O, Kawai T, Kaisho T, Sato S, Sanjo H, Matsumoto M, Hoshino K, Wagner H, Takeda K, Akira S: A Toll-like receptor recognizes bacterial DNA. Nature 2000;408:740-745.

4 Liu YJ: IPC: professional type 1 interferonproducing cells and plasmacytoid dendritic cell precursors. Annu Rev Immunol 2005;23: 275-306.

5 Griebel PJ, Brownlie R, Manuja A, Nichani A, Mookherjee N, Popowych Y, Mutwiri G, Hecker R, Babiuk LA: Bovine Toll-like receptor 9: a comparative analysis of molecular structure, function and expression. Vet Immunol Immunopathol 2005;108:11-16.

-6 Bernasconi NL, Onai N, Lanzavecchia A: A role for Toll-like receptors in acquired immunity: up-regulation of TLR9 by BCR triggering in naive $\mathrm{B}$ cells and constitutive expression in memory B cells. Blood 2003;101: 4500-4504.

7 Bourke E, Bosisio D, Golay J, Polentarutti N, Mantovani A: The Toll-like receptor repertoire of human B lymphocytes: inducible and selective expression of TLR9 and TLR10 in normal and transformed cells. Blood 2003; 102:956-963.

$\checkmark 8$ Krieg AM, Yi AK, Matson S, Waldschmidt TJ, Bishop GA, Teasdale R, Koretzky GA, Klinman DM: CpG motifs in bacterial DNA trigger direct B-cell activation. Nature 1995; 374:546-549.

9 Lin L, Gerth AJ, Peng SL: CpG DNA redirects class-switching towards 'Th1-like' Ig isotype production via TLR9 and MYD88. Eur J Immunol 2004;34:1483-1487.

10 Krieg AM: CpG motifs in bacterial DNA and their immune effects. Annu Rev Immunol 2002;20:709-760.

- 11 He B, Qiao X, Cerutti A: CpG DNA induces IgG class switch DNA recombination by activating human $B$ cells through an innate pathway that requires TLR9 and cooperates with IL-10. J Immunol 2004;173:4479-4491.
Booth JS, Griebel PJ, Babiuk LA, Mutwiri GK: A novel regulatory B-cell population in sheep Peyer's patches spontaneously secretes IL-10 and downregulates TLR9-induced IFNalpha responses. Mucosal Immunol 2009;2:265-275.

13 Gerdts V, Babiuk LA, van Drunen Littel-van den Hurk S, Griebel PJ: Fetal immunization by a DNA vaccine delivered into the oral cavity. Nat Med 2000;6:929-932.

14 Mutwiri G, Watts T, Lew L, Beskorwayne T, Papp Z, Baca-Estrada ME, Griebel P: Ileal and jejunal Peyer's patches play distinct roles in mucosal immunity of sheep. Immunology 1999;97:455-461.

15 Hope JC, Kwong LS, Entrican G, Wattegedera S, Vordermeier HM, Sopp P, Howard CJ: Development of detection methods for ruminant interleukin (IL)-12. J Immunol Methods 2002;266:117-126.

16 Kwong LS, Hope JC, Thom ML, Sopp P, Duggan S, Bembridge GP, Howard CJ: Development of an ELISA for bovine IL-10. Vet Immunol Immunopathol 2002;85:213-223.

17 Griebel P, Beskorwayne T, van den Broeke A, Ferrari G: CD40 signaling induces $B$ cell responsiveness to multiple members of the gamma chain-common cytokine family. Int Immunol 1999;11:1139-1147.

18 Menzies M, Ingham A: Identification and expression of Toll-like receptors 1-10 in selected bovine and ovine tissues. Vet Immunol Immunopathol 2006;109:23-30.

19 Jalal S, Arsenault R, Potter AA, Babiuk LA, Griebel PJ, Napper S: Genome to kinome: species-specific peptide arrays for kinome analysis. Sci Signal 2009;2:pl1.

20 Malaspina A, Moir S, Di Poto AC, Ho J, Wang W, Roby G, O'Shea MA, Fauci AS: CpG oligonucleotides enhance proliferative and effector responses of B cells in HIV-infected individuals. J Immunol 2008; 181: 1199-1206.

21 Wagner M, Poeck H, Jahrsdoerfer B, Rothenfusser S, Prell D, Bohle B, Tuma E, Giese T, Ellwart JW, Endres S, Hartmann G: IL12p70-dependent Th1 induction by human $B$ cells requires combined activation with CD40 ligand and CpG DNA. J Immunol 2004;172:954-963.
22 Ozes ON, Mayo LD, Gustin JA, Pfeffer SR, Pfeffer LM, Donner DB: Nf-kappab activation by tumour necrosis factor requires the Akt serine-threonine kinase. Nature 1999; 401:82-85.

23 Sasaki T, Kojima H, Kishimoto R, Ikeda A, Kunimoto H, Nakajima K: Spatiotemporal regulation of c-Fos by ERK 5 and the e3 ubiquitin ligase UBR1, and its biological role. Mol Cell 2006;24:63-75.

24 Huang WC, Chen JJ, Inoue H, Chen CC: Tyrosine phosphorylation of I-kappa B kinase alpha/beta by protein kinase $\mathrm{C}$-dependent $\mathrm{C}$ SRC activation is involved in TNF-alpha-induced cyclooxygenase-2 expression. J Immunol 2003;170:4767-4775.

25 Singhirunnusorn P, Suzuki S, Kawasaki N, Saiki I, Sakurai H: Critical roles of threonine 187 phosphorylation in cellular stress-induced rapid and transient activation of transforming growth factor-beta-activated kinase 1 (TAK1) in a signaling complex containing TAK1-binding protein TAB1 and TAB2. J Biol Chem 2005;280:7359-7368.

26 Salvador JM, Mittelstadt PR, Guszczynski T, Copeland TD, Yamaguchi H, Appella E, Fornace AJ Jr, Ashwell JD: Alternative p38 activation pathway mediated by $\mathrm{T}$ cell receptorproximal tyrosine kinases. Nat Immunol 2005;6:390-395.

27 Daub H, Olsen JV, Bairlein M, Gnad F, Oppermann FS, Korner R, Greff Z, Keri G, Stemmann O, Mann M: Kinase-selective enrichment enables quantitative phosphoproteomics of the kinome across the cell cycle. Mol Cell 2008;31:438-448.

28 Pathak SK, Basu S, Bhattacharyya A, Pathak S, Banerjee A, Basu J, Kundu M: TLR4-dependent NF-kappaB activation and mitogen- and stress-activated protein kinase 1-triggered phosphorylation events are central to Helicobacter pylori peptidyl prolyl cis-, trans-isomerase (HP0175)-mediated induction of IL-6 release from macrophages. J Immunol 2006;177:7950-7958.

29 Teusch N, Lombardo E, Eddleston J, Knaus UG: The low molecular weight GTPase rhoA and atypical protein kinase Czeta are required for TLR2-mediated gene transcription. J Immunol 2004;173:507-514. 
30 Mattioli I, Geng H, Sebald A, Hodel M, Bucher C, Kracht M, Schmitz ML: Inducible phosphorylation of NF-kappa B p 65 at serine 468 by $\mathrm{T}$ cell costimulation is mediated by IKK epsilon. J Biol Chem 2006;281:61756183.

31 Chen BC, Wu WT, Ho FM, Lin WW: Inhibition of interleukin-1beta -induced NF-kappa $\mathrm{B}$ activation by calcium/calmodulin-dependent protein kinase kinase occurs through AKT activation associated with interleukin-1 receptor-associated kinase phosphorylation and uncoupling of MYD88. J Biol Chem 2002;277:24169-24179.

- 32 Kollewe C, Mackensen AC, Neumann D, Knop J, Cao P, Li S, Wesche H, Martin MU: Sequential autophosphorylation steps in the interleukin-1 receptor-associated kinase-1 regulate its availability as an adapter in interleukin-1 signaling. J Biol Chem 2004;279: 5227-5236.

-33 Alappat EC, Feig C, Boyerinas B, Volkland J, Samuels M, Murmann AE, Thorburn A, Kidd VJ, Slaughter CA, Osborn SL, Winoto A, Tang WJ, Peter ME: Phosphorylation of FADD at serine 194 by CKIalpha regulates its nonapoptotic activities. Mol Cell 2005;19: 321-332.
34 Alvarado-Kristensson M, Melander F, Leandersson K, Ronnstrand L, Wernstedt C, Andersson T: p38-MAPK signals survival by phosphorylation of caspase- 8 and caspase- 3 in human neutrophils. J Exp Med 2004;199: 449-458.

35 Langer T, Vogtherr M, Elshorst B, Betz M, Schieborr U, Saxena K, Schwalbe H: NMR backbone assignment of a protein kinase catalytic domain by a combination of several approaches: application to the catalytic subunit of cAMP-dependent protein kinase. Chembiochem 2004;5:1508-1516.

36 Kishimoto K, Matsumoto K, Ninomiya-Tsuji J: Tak1 mitogen-activated protein kinase kinase kinase is activated by autophosphorylation within its activation loop. J Biol Chem 2000;275:7359-7364.

37 Sakurai H, Nishi A, Sato N, Mizukami J, Miyoshi H, Sugita T: Tak1-Tabl fusion protein: a novel constitutively active mitogen-activated protein kinase kinase kinase that stimulates AP-1 and NF-kappaB signaling pathways. Biochem Biophys Res Commun 2002; 297:1277-1281.
38 Deng T, Karin M: c-Fos transcriptional activity stimulated by h-ras-activated protein kinase distinct from JNK and ERK. Nature 1994;371:171-175.

-39 Jirmanova L, Sarma DN, Jankovic D, Mittelstadt PR, Ashwell JD: Genetic disruption of p38alpha Tyr323 phosphorylation prevents T-cell receptor-mediated p38alpha activation and impairs interferon-gamma production. Blood 2009;113:2229-2237.

40 Mizoguchi A, Bhan AK: A case for regulatory B cells. J Immunol 2006; 176:705-710.

41 Chuang TH, Ulevitch RJ: Triad3a, an e3 ubiquitin-protein ligase regulating Toll-like receptors. Nat Immunol 2004;5:495-502.

42 An H, Hou J, Zhou J, Zhao W, Xu H, Zheng Y, Yu Y, Liu S, Cao X: Phosphatase SHP-1 promotes TLR- and RIG-I-activated production of type I interferon by inhibiting the kinase IRAK1. Nat Immunol 2008;9:542-550.

43 Wang J, Hu Y, Deng WW, Sun B: Negative regulation of Toll-like receptor signaling pathway. Microbes Infect 2009;11:321-327. 